\title{
EFFECT OF USING PORTFOLIO ASSESSMENT TO IMPROVE SCIENTIFIC ATTITUDE OF STUDENTS LEARNING PHYSICS IN HIGH SCHOOL
}

\author{
Wartawan Putu Gede ${ }^{1, *}$
}

Guru Fisika SMA Negeri 4 Singaraja Bali Indonesia *putugedewartawan@gmail.com

\begin{abstract}
This study aims to investigate the effect of portfolio assessment in teaching physics and scientific attitude. The research was conducted on students of high school in Singaraja. Research was an quasi- experimental study by using "The Posttest-Only Control Group Design". The research involved 152 high school students of class $\mathrm{X}$ of science as samples, taken with multistage random sampling technique. Portfolio assessment was integrated with physics learning. The implementation of the portfolio assessment included four key elements such as the students' work folders, clear assessment criteria, and self-assessment, and conference between teacher and students. The data needed in this research was the students' scientific attitude which included the aspect of curiosity, respect for evidence, the willingness to change ideas, and critical reflection. Data needed in this research included scientific attitudes students. A Likert scale instrument was used to measure the scientific attitude students. Data were analyzed using analysis of variance with SPSS 20.0 at significance level $\alpha=0.05$. The results showed there are differences in the scientific attitude students who take physics learning with assessment portfolios and students who take physics learning with assessment of conventional. The findings of this study indicate that portfolio assessment in learning physics significantly affect the scientific attitude students.
\end{abstract}

Keywords: portfolio assessment, scientific attitude

\section{INTRODUCTION}

The rapid development of science and technology that has a leading position in the exploration of natural phenomena thus could not be separated. Marjorie states that learning science provides the practice of scientific method which develops the scientific attitude, which lead us to think critically and value facts with evidence [1]. Physics as part of science naturally has an integrated concept of thought and understanding in the development of systematic thinking and analysis. Physics essentially includes three things: physics as a process, a product, and a scientific attitude. Therefore, the study of physics in educational institutions particularly in high school should be capable of producing skilled and capable students in developing mental processes to understand nature and its symptoms, developing and applying the concepts of physics and having a scientific attitude that enables them to think and act scientifically.

Pitafi dan Farooq states that a scientific attitude investigates for a certain scientific act or thought [2]. Mukhopadhyay states that a scientific attitude is a characteristic of a scientist [3]. The scientist is someone who solves the problem, who is accustomed to doing research and testing in a planned manner so that a new finding is obtained. Harlen distinguishes two kinds of scientific attitudes: 1) those towards science as an enterprise, 2) those towards objects and events in the environment which are studied in the course of scientific activities [4]. In order for students to have a positive attitude toward science then they must have a correct view of science. This can be done by building a scientific attitude, which includes curiosity, respect for fevidence, a willingness to change ideas, and critical reflection.

However, it should be admitted that the results of education in the field of science and especially physics in Indonesia is still far from expectations. The low quality of Indonesian human resources in global competition, especially in the field of science and physics can be seen from the report of the Program for International Student Assessment (PISA), an international systematic assessment that measures the ability of 15 -year-old students in literacy reading, mathematics, and science every three years. The results of the PISA study in 2012 placed Indonesia's position at the 64th position of 65 countries participating in the test. This shows that the ability of Indonesian children aged 15 years in the field of reading, math, and science than other children in the world is still low. 
The low scientific attitude of students is certainly a result of the not successful physics learning process is implemented. There are many factors that affect the low scientific attitude of students. One of the predominant factors influencing students' scientific attitude is the assessment used by teachers in assessing physics learning process and outcomes. In the learning cycle, assessment is one of the stages which role is very important and cannot be ignored. Marhaeni said that at least assessment activities can produce two things: first, as feedback on the learning process, and second, can provide information about the quality of acquisition in the subject of students [5]. Suastra states assessment can be used to diagnose the trengths and weakness ot the students, to monitor their progress, to determine their rangking, and to determine the effecveness of instruction done by the teacher [6].

Many efforts have been done to improve the quality of physics learning in Indonesia. Some of the efforts done were providing laboratory facilities and infrastructure $\&$ libraries, improving the quality of teachers through education and training, and curriculum improvement. In the 2013 curriculum, there was a revision of the implementation of learning by using scientific approach. Learning in scientific approach is a learning that adopts the steps of scientists in building knowledge through scientific methods. The scientific approach consists of five basic learning experiences: 1) observing, 2) questioning, 3) attempting / collecting data, 4) associating, and 5) communicating.

An assessment model that is compatible with learning with a scientific approach is portfolio assessment. Salvia and Ysseldike define that portfolio is a collection of products used to demonstrate what a person is capable of doing [7]. Dantes, et al quoted Paulson and Paulson who define the portfolio as a purposeful collection of student work the exhibits that the student's efforts, progress and achievement in one ormoreareas. The collection must include student participation in selection, the criteria for selection, the criteria for judging merit and evidence of student self-reflection [8].

Portfolio assessment is an ongoing assessment based on a collection of information that demonstrates the development of learners' abilities within a given period. Through the portfolio assessment teachers will know the progress of learners. For example, the results of their work in preparing or making practical reports. On the basis of the assessment, teachers and learners can make improvements in accordance with the demands of learning.

This study aims to investigate the effect of portfolio assessment in teaching physics and scientific attitude. Research was an quasi- experimental study by using "The Posttest-Only Control Group Design”. The results showed there are differences in the scientific attitude students who take physics learning with assessment portfolios and students who take physics learning with assessment of conventional. The findings of this study indicate that portfolio assessment in learning physics significantly affect the scientific attitude students.

\section{METHODS}

This research was conducted at students of high cshool in Singaraja City using quasi experiment method with "The Posttest-Only Control Group Design". This study involved 152 high school students of class X of science as research sample, taken with multistage random sampling technique.

Table 1. Distribution of Experiment Group and Control Group Members

\begin{tabular}{cccccc}
\hline \multirow{2}{*}{ No } & \multirow{2}{*}{ High School } & \multicolumn{2}{c}{ Experimental Group } & \multicolumn{2}{c}{ Control Group } \\
\cline { 2 - 5 } & SMA Negeri 2 Singaraja & Class & Xumber & Class & Number \\
\hline 1 & Science 1 & 35 students & X of science 3 & 38 students \\
\hline 2 & SMA Negeri 4 Singaraja & X of science 7 & 40 students & X of science 5 & 39 students \\
\hline \multicolumn{2}{c}{ Number } & 2 & 75 students & 2 & 77 students \\
\hline
\end{tabular}


The treatment variables that were experimented in this study were portfolio assessment. The experimental group follow physics learning with a portfolio assessment, and a control group with a conventional assessment. Portfolio assessment in physics learning that is carried out is the assessment of the process of preparation and product of physics learning tasks in the form of practical reports. After the treatment, data were taken on the students' scientific attitude through the scientific attitude questionnaire.

To measure the scientific attitude variable, the scientific attitude questionnaire was used with the reliability coefficient of 0.960 . The scientific questionnaire consisted of 41 items, with ideal minimum score $=1$ and ideal maximum score $=205$.

Hypothesis testing using variance analysis of SPSS 20.0 program at significance level $\alpha=0.05$. Preparation test data analysis performed before hypothesis testing includes testing the normality of data distribution and homogeneity of group variance.

\section{RESULTS AND DISCUSSION}

Recapitulation of descriptive analysis of scientific attitude scores results is presented in Table 2.

Table 2. Recapitulation of descriptive analysis of scientific attitude

\begin{tabular}{lcc}
\hline \multicolumn{1}{c}{ Statistics } & Portfolio Assessment & Conventional Assessment \\
\hline Mean & 164,63 & 148,92 \\
\hline Standard Deviation & 9,83 & 2,67 \\
\hline
\end{tabular}

Scientific attitude data of students who follow physics learning with portfolio assessment have mean $=164,63$ and standard deviation 9,83. Referring to the classification of scores, scientific attitude data of students who follow physics learning with portfolio assessment is in the high category. Score data of students' scientific attitude following physics study with conventional assessment had mean score $=148,92$ and standard deviation 11,54 . Referring to the score classification, students' scientific attitude data following physics learning with conventional assessment is in the high category.

The following table shows the result of analysis of students' scientific attitude in each dimension.

Table 3. Description of Scientific Attitude Dimensions

\begin{tabular}{lcccc}
\hline \multirow{2}{*}{ Dimension } & \multicolumn{2}{c}{ Portfolio Assessment } & \multicolumn{2}{c}{ Conventional Assessment } \\
\cline { 2 - 5 } & Mean & Category & Mean & Category \\
\hline Curiosity & 42,45 & high & 41,82 & High \\
\hline Respect for evidence & 36,32 & high & 36,68 & High \\
\hline Willingness to change ideas & 40,49 & high & 34,78 & Average \\
\hline critical reflection & 45,49 & high & 36,65 & Average \\
\hline
\end{tabular}

Further finding on the description of scientific attitude in each dimension for students who learned physic with portfolio assessment are in high category for all dimension (curiosity, respect for evidence, willingness to change ideas, and critical reflection). Whilst, the descriptions of scientific attitude for students' who learned physic with conventional assessment are in high category for two dimensions (curiosity and respect for evidence), and average category for the other two dimensions (willingness to change ideas and critical reflection)

The followings are the results of the data analysis using SPSS 20.0 with significance level $\alpha=0,05$. 
Table 4. Test of Between Subject Effects

Dependen Variabel: Y

\begin{tabular}{lrrrrr}
\hline \multicolumn{1}{c}{ Sourch } & \multicolumn{1}{c}{$\begin{array}{c}\text { Type III Sum } \\
\text { of Squares }\end{array}$} & df & Mean Square & F & Sig. \\
\hline Corrected Model & $9370.473^{\text {a }}$ & 1 & 9370.473 & 81.374 & .000 \\
Intercept & 3735240.184 & 1 & 3735240.184 & 32436.951 & .000 \\
A & 9370.473 & 1 & 9370.473 & 81.374 & .000 \\
Error & 17273.079 & 150 & 115.154 & & \\
Total & 3757608.000 & 152 & & & \\
Corrected Total & 26643.553 & 151 & & & \\
\hline
\end{tabular}

a. $\quad$ R Squared $=.352$ (Adjusted R Squared $=.347$

The result of analysis of difference of scientific attitude between students who follow physics learning with portfolio assessment and students who follow physics learning with conventional assessment using variance analysis with the SPSS 20.0 program at significance level $\alpha=0,05$ yield value $F=81,347$ and significance number $<0,05$. The results of this study indicate that the assessment of portfolio in physics learning has a significant effect on students' scientific attitude.

Table 5. Pairwise Comparisons

\section{Dependen Variabel: Y}

\begin{tabular}{|c|c|c|c|c|c|c|}
\hline \multirow[t]{2}{*}{ (I)A } & \multirow[t]{2}{*}{ (J)A } & \multirow{2}{*}{$\begin{array}{c}\text { Mean Difference } \\
(\mathrm{I}-\mathrm{J})\end{array}$} & \multirow[b]{2}{*}{ Std. Error } & \multirow[b]{2}{*}{ Sig. ${ }^{b}$} & \multicolumn{2}{|c|}{$\begin{array}{c}95 \% \text { Confidence Interval for } \\
\text { Difference }^{\mathrm{b}}\end{array}$} \\
\hline & & & & & Lower Bound & Upper Bound \\
\hline 1.00 & 2.00 & $15.705^{*}$ & 1.741 & .000 & 12.265 & 19.145 \\
\hline 2.00 & 1.00 & $-15.705^{*}$ & 1.741 & .000 & -19.145 & -12.265 \\
\hline
\end{tabular}

Based on estimated marginal means

*The mean difference is significant at the .005 level

${ }^{\mathrm{b}}$ Adjustment for multiple comparisons: Least Significant Difference (equivalent to no adjustments)

The result of pairwise comparison shows that the mean difference between the group who learned physic with portfolio assessment and those who learned physic with conventional assessment is 15.705 with level of significance < 0.05. It means that students who learned physic with portfolio assessment has significantly higher scientific attitude than students who learned physic with conventional assessment.

The findings above show that implementing portfolio assessment in physic teaching and learning gives positive effect to the students' scientific attitude. This positive effect is because of the characteristic of portfolio assessment in physic teaching and learning, which are the result of students and teacher collaboration, selection process, self-assessment, and clear criteria of portfolio assessment.

Portfolio assessment through collection of product in physic teaching and learning in the form of experiment report increases the students' scientific attitude effectively. In writing the experiment report the students presents the process of finding a physic product. In this process, students use scientific method. In the process of writing the experiment report by using the given format, which involves self-reflection and self-assessment, discussion and feedback, and assessment by using the agreed rubric, the teacher will be able to recognize the students' mental process. The scientific method that is done by the students will encourage them to develop their scientific attitude which consists of curiosity, respect of evidence, willingness to change ideas, and critical reflection.

The result in this study in line with the research done by Chi-Cheng Chang, Kuo-Hung Tseng, dan Shi-Jer Lou, which found that using portfolio in physic teaching and learning helps students in developing their idea through self reflection and self assessment, and also discussion which gives students feedback so the students gain ideas in writing their experiment report. This process will encourage students to revise their work. It means that students have 
willingness to change ideas, which is one of the aspects of scientific stain [9]. The result of this study also supports the study done by Mohammad Tawiland which found that the implementation of portfolio assessment in teaching and learning develops higher critical reflection compared to conventional assessment [10]. Further, Pramudya Dwi found that developing and implementing authentic assessment improve students' achievement in cognitive, psychomotor, and affective. These three aspects are the reflection of the scientific thinking ability of students in physic education program [11].

\section{CONCLUTION}

Based on the results of hypothesis testing as described, it can be concluded "There is a significant difference in scientific attitude between students who follow physics learning with portfolio assessment and students who follow physics learning with conventional assessment". Further analysis results show that students' scientific attitude following physics learning with portfolio assessment is higher than that of students following physics learning with conventional assessment. This means that portfolio assessment is one of the factors that can be used to improve scientific attitudes.

\section{ACKNOWLEDGEMENTS}

We would like to thank the head master of SMA Negeri 2 Singaraja and head master of SMA Negeri 4 Singaraja who given permission for the research, as well as students involved the study. The author thanks, all supporter at completing this article to be published.

\section{REFERENCES}

1. M. Lacap, "The Scientific Attitudes of Students Major In Science in the New Teacher Educaton Curriculum," Asia Pacific Journal of Multidisciplinary Research, 3, 7, (2015)

2. A. Pitafi, \& M. Farooq, "Measurment of Scientific Attitude of Secondary School Students in Pakistan," Academic Research International, 2, 383 (2012)

3. R. Mukhopadhyay, "Scientific Attitude - Some Psychometric Considerations," IOSR Journal Of Humanities And Social Science (IOSR-JHSS) OSR-JHSS, 19, 98-100 (2014)

4. W. Harlen, The Teaching of Science, 40 (1991).

5. A. Marhaeni, "Effect of Portfolio Assessment and Achievement Motivation in Learning English on English Writing Ability," Dissertation (not published), 2 (2005)

6. S. Wayan, R. Putu, "Problem Faced by Teacher in Designing and Implementing Authentic Assessment in Science Teaching," International Research Journal of Enginering, IT \& Scientific Research (IRJEIS), 3, 24 - 32 (2017)

7. J. Salvia \& J.E. Ysseldike, Assessment, $6^{\text {th }}$ Edition, 293 (1996)

8. D. Nyoman, S. Wayan, S. Wayan. Classroom Based Assessment Guidelines for Cluster of Science Lessons, 7 (2006)

9. C. Chang, K. Tseng, dan S.Jer Lou, "A Comparative Analysis of the Consistency and Difference Among TeacherAssesment, Student Self-Assesment and Peer-Assesment in Web-Based Portfolio Assesment Environment for High School Students," International Journal of Computers \& Education, 58, 303 - 320 (2012)

10. M. Tawilan, "Portfolio-Based Physics Learning Model to Improve Critical Thinking Skills," International Journal of Education and Research, 9, 1 - 8 (2013)

11. P. Dwi, "Portfolio-Based Physics Learning Model to Improve Critical Thinking Skills," International Journal of Education and Research, 15, 184 (2013) 